Review

\title{
Drug Resistance and Endoplasmic Reticulum Stress in Hepatocellular Carcinoma
}

\author{
Jaafar Khaled $^{1}$, Maria Kopsida ${ }^{1}$, Hans Lennernäs ${ }^{2}(D)$ and Femke Heindryckx ${ }^{1, * \mathbb{D}}$ \\ 1 Medical Cell Biology, Uppsala University, 75105 Uppsala, Sweden; jaafar.khaled@mcb.uu.se (J.K.); \\ maria.kopsida@mcb.uu.se (M.K.) \\ 2 Pharmaceutical Biosciences, Uppsala University, 75105 Uppsala, Sweden; hans.lennernas@farmbio.uu.se \\ * Correspondence: femke.heindryckx@mcb.uu.se
}

check for updates

Citation: Khaled, J.; Kopsida, M.; Lennernäs, H.; Heindryckx, F. Drug Resistance and Endoplasmic Reticulum Stress in Hepatocellular Carcinoma. Cells 2022, 11, 632. https://doi.org/10.3390/ cells11040632

Academic Editor: Ali Canbay

Received: 26 December 2021

Accepted: 8 February 2022

Published: 11 February 2022

Publisher's Note: MDPI stays neutral with regard to jurisdictional claims in published maps and institutional affiliations.

Copyright: (C) 2022 by the authors. Licensee MDPI, Basel, Switzerland. This article is an open access article distributed under the terms and conditions of the Creative Commons Attribution (CC BY) license (https:// creativecommons.org/licenses/by/ $4.0 /)$.

\begin{abstract}
Hepatocellular carcinoma (HCC) is one of the most common and deadly cancers worldwide. It is usually diagnosed in an advanced stage and is characterized by a high intrinsic drug resistance, leading to limited chemotherapeutic efficacy and relapse after treatment. There is therefore a vast need for understanding underlying mechanisms that contribute to drug resistance and for developing therapeutic strategies that would overcome this. The rapid proliferation of tumor cells, in combination with a highly inflammatory microenvironment, causes a chronic increase of protein synthesis in different hepatic cell populations. This leads to an intensified demand of protein folding, which inevitably causes an accumulation of misfolded or unfolded proteins in the lumen of the endoplasmic reticulum (ER). This process is called ER stress and triggers the unfolded protein response (UPR) in order to restore protein synthesis or-in the case of severe or prolonged ER stress-to induce cell death. Interestingly, the three different arms of the ER stress signaling pathways have been shown to drive chemoresistance in several tumors and could therefore form a promising therapeutic target. This review provides an overview of how ER stress and activation of the UPR contributes to drug resistance in HCC.
\end{abstract}

Keywords: unfolded protein response; endoplasmic reticulum stress; liver cancer; drug resistance; transarterial chemoembolization; anthracyclins; tumor microenvironment

\section{Introduction}

Hepatocellular carcinoma (HCC) is a primary liver tumor that contributes to over 550,000 annual deaths worldwide [1,2]. It usually develops in a background of chronic liver disease, which can be caused by alcohol-related liver diseases, chronic hepatitis infections, non-alcoholic fatty liver disease, and genetic mutations [3-5]. Each of these risk factors is characterized by a chronic perpetuation of liver injury that creates an inflammatory and a pro-tumoral microenvironment that sustains cancer cell proliferation and survival $[6,7]$. There is accumulating evidence that endoplasmic reticulum (ER) stress plays a pivotal role in chronic inflammation and carcinogenesis, and that in some cases, ER stress may even contribute to the initiation of these conditions [8-10]. Components of the ER are essential for folding proteins into their native three-dimensional (3D) conformations needed to perform their intended reactions and functions $[8,9,11]$. However, as protein translation increases in times of high cellular activity or stress, efficacy of ER components may decrease, leading to an accumulation of misfolded and unfolded proteins in the ER lumen. These misfolded proteins are often unable to leave the ER and may eventually trigger a signaling cascade that initiates the unfolded protein response (UPR) through three different ER stresssignaling branches: protein kinase RNA-like ER kinase (PERK), inositol-requiring enzyme 1 (IRE1 $\alpha$ ), and activating transcription factor 6 (ATF6). The UPR may also be elicited through other forms of stress that occur in the inflammatory microenvironment, as well as within rapidly proliferating tumor cells. Such triggers include an increased generation of reactive 
oxygen species (ROS), hypoxia, nutrient starvation, exposure to chemotherapeutic drugs and improper calcium homeostasis [12]. The activation of the UPR will primarily attempt to reduce the load of the ER, for instance by decelerating protein translation or by increasing the ER's folding capacity. However, in cases of prolonged or severe ER stress, pro-survival and pro-apoptotic pathways will be initiated.

Hepatocellular carcinoma has several complex factors that contribute to its development and progression, in addition to mechanisms that can directly or indirectly interfere with treatment efficacy. One of the most alarming complications in HCC is occurrence of multidrug resistance. This means that efficacy of chemotherapeutic drugs become severely reduced due to cancer cells utilizing different biological tools to remove, convert, and/or disarm drugs intended to interfere with them [13-16]. This review focuses on how HCC cells harness ER stress to survive and adopt a drug resistant phenotype through several complex and intertwined resistance mechanisms (Figure 1).

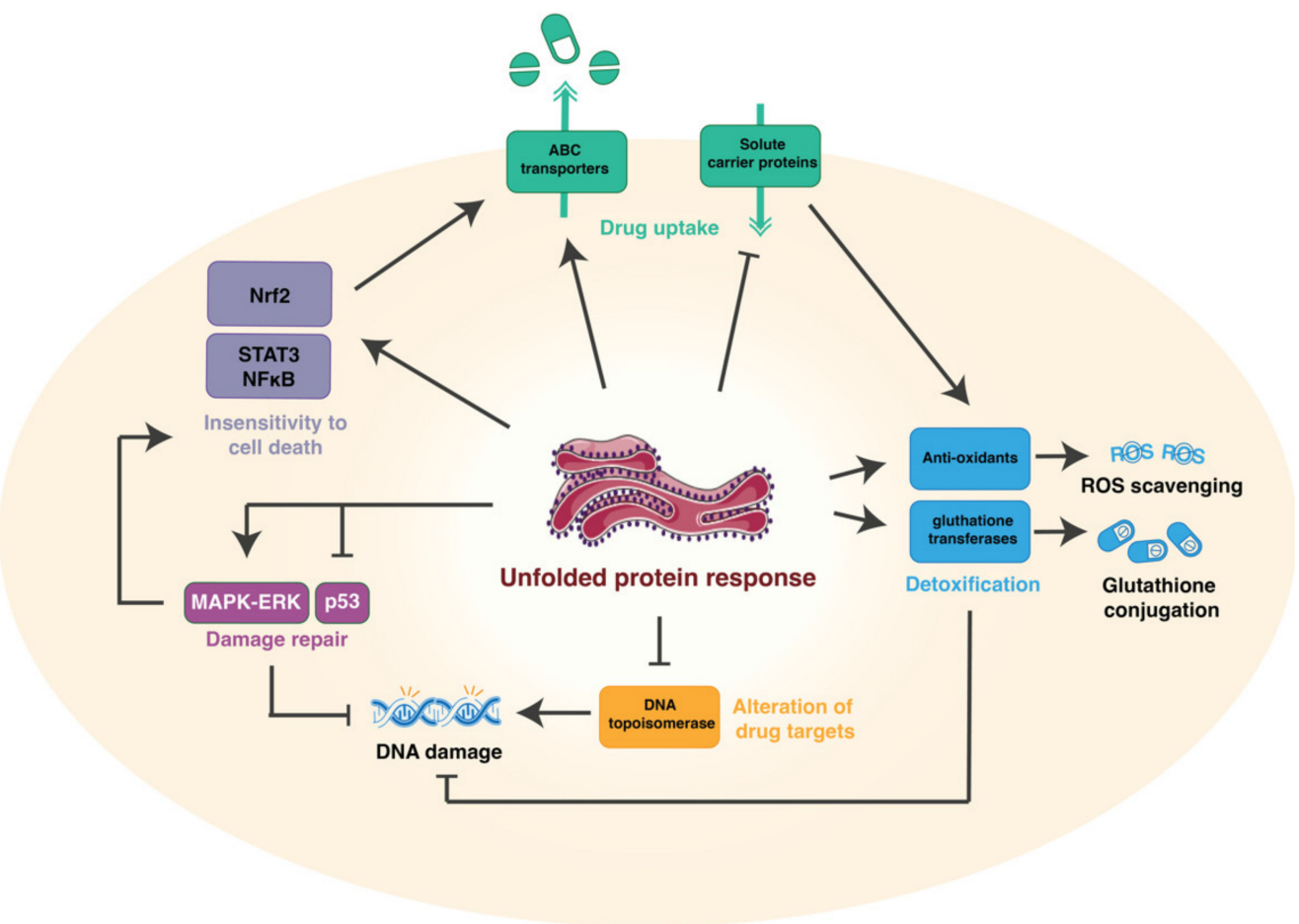

Figure 1. There are five mechanisms on how tumor cells acquire drug resistance. Firstly, reduction of drug uptake by increased efflux and decreased influx of chemotherapeutics through ABC transporters and solute carrier proteins, respectively. Secondly, alteration of the drug targets, for instance by decreasing protein expression of DNA topoisomerase, an important target of doxorubicin, which is responsible for inducing DNA strand breaks during doxorubicin treatment. Thirdly, by induction of drug-detoxifying mechanisms, such as scavenging of reactive oxygen species (ROS) or by nucleophilic conjugation of glutathione to the active site of chemotherapeutics, which is mediated by glutathione transferase enzymes. Fourthly, by repairing drug-induced damages, such as DNA damage, which can be directly induced by chemotherapeutics or through oxidative stress. Lastly, by inducing insensitivity to cell death through activation of several pathways, including NFkB, STAT3, and Nrf2. These five molecular mechanisms are heavily intertwined, thereby often accelerating the drug-resistant phenotype of hepatocellular carcinoma.

\section{Endoplasmic Reticulum Stress in Health and Disease}

Under normal conditions, the ER is an organelle that manages synthesis and folding of proteins [8,9] while also functioning as a storage unit for calcium ions, lipid synthesis, and fatty acid oxidation [17]. When the cell's need for protein folding exceeds the ER's capacity to accurately fold proteins, an accumulation of unfolded and misfolded proteins 
will occur, thereby triggering the UPR. Activation of the mammalian UPR occurs through three ER stress pathways that ultimately regulate transcription of genes that influence protein folding, folding capacity, autophagy, and apoptosis [8]. Accumulation of unfolded or misfolded proteins is sensed via three transmembrane receptors: PERK, IRE $1 \alpha$, and ATF6, which remain inactive when they are bound to ER chaperone GRP78/BiP (78-kDa glucose-regulated protein) [8]. Activation of the different ER stress branches is thought to be based on two models, namely, the direct and indirect recognition models. The direct recognition model proposes that UPR activation arises when GRP78/BiP dissociates from the luminal binding domains of the PERK/ATF6/IRE1 $\alpha$ receptors [8,11]. GRP78/BiP has a greater affinity for unfolded proteins than their ER stress receptor domain and therefore dissociates when unfolded protein concentrations increase [17]. During low levels of ER stress, activation of these pathways is correlated to increased translation of genes regulating ER chaperones, amino acid metabolism, redox reactions, autophagy, protein folding, and maturation, which is generally thought of as a pro-survival mechanism [8-11]. In comparison, high levels or prolonged ER stress have been shown to trigger apoptotic pathways via caspase-3, BCL-2 family member, apoptosome complex activation, and ferroptosis [17-19]. How and when different ER stress pathways exert their cytoprotective or their pro-apoptotic functions remains largely unknown. The duration and severity of ER stress seems to be a major contributor to the switch towards apoptosis, possibly by inducing changes in the conformational structure of IRE1 $\alpha[17,20]$. A second theory suggests that transcription factor E2F1 plays a role of a kill switch during late-stage ER stress, where expression levels of E2F1 will determine whether the cell locks onto survival or apoptotic pathways [17]. The threshold at which cells experience a severe and prolonged ER stress that would induce apoptosis varies among different cell lines, depending on their translational capacity (e.g., number of chaperones, ER size, and the amount of machinery for protein degradation) and differences in intrinsic sources of ER stress [21,22].

The rapid proliferation of tumor cells is accompanied by an acute increase of protein synthesis, which inevitably leads to activation of the UPR. It is therefore not surprising that actors of the UPR are increased in nearly all cancer types and that ER stress pathways seem to be affecting every hallmark of cancer $[23,24]$. Studies have shown that HCC cells hijack ER stress pathways to keep cells in a pro-survival signaling loop, while also interfering with components of the pro-apoptotic pathways [8,17]. Hypoxia and nutrient deprivation can directly activate the UPR [25] and have also been implicated as strong inducers of chemoresistance [13]. It has been further suggested that tumor cells modulate the UPR to aid in secreting pro-survival cytokines, growth factors, and other components, which consequently modulate cells in their immediate microenvironment to proliferate safely while suppressing an immune response [26,27]. To sustain their own metabolic demands and to adapt to a challenging and rapidly changing environment, cancer cells also reprogram their secretome to further support tumor function and induce chemoresistance. A thorough understanding of how ER stress pathways are intertwined with different mechanisms of drug resistance will therefore enable development of new chemotherapeutic candidates and optimize existing treatments in order to achieve better response.

\section{Mechanisms of Drug Resistance}

In recent decades, chemotherapy and targeted therapies have become principal modes of treatment against most types of cancer, including HCC. However, their efficacy is limited due to various inherent and acquired resistance mechanisms developed by cancer cells. This is specifically relevant in HCC, as most chemotherapeutics have limited efficiency due to the high intrinsic resistance of hepatic cancer cells [16]. Five different mechanisms have been described on how tumor cells acquire drug resistance: (1)—reduction of drug uptake, (2) - alteration of the drug target, (3)-induction of drug-detoxifying mechanisms, (4) - repair of drug-induced damage, and (5) - insensitivity to drug-induced cell death [14] (Figure 1). The three different arms of the ER stress signaling pathways are involved in the induction of chemoresistance throughout all these different mechanisms (Figure 2) [10]. 


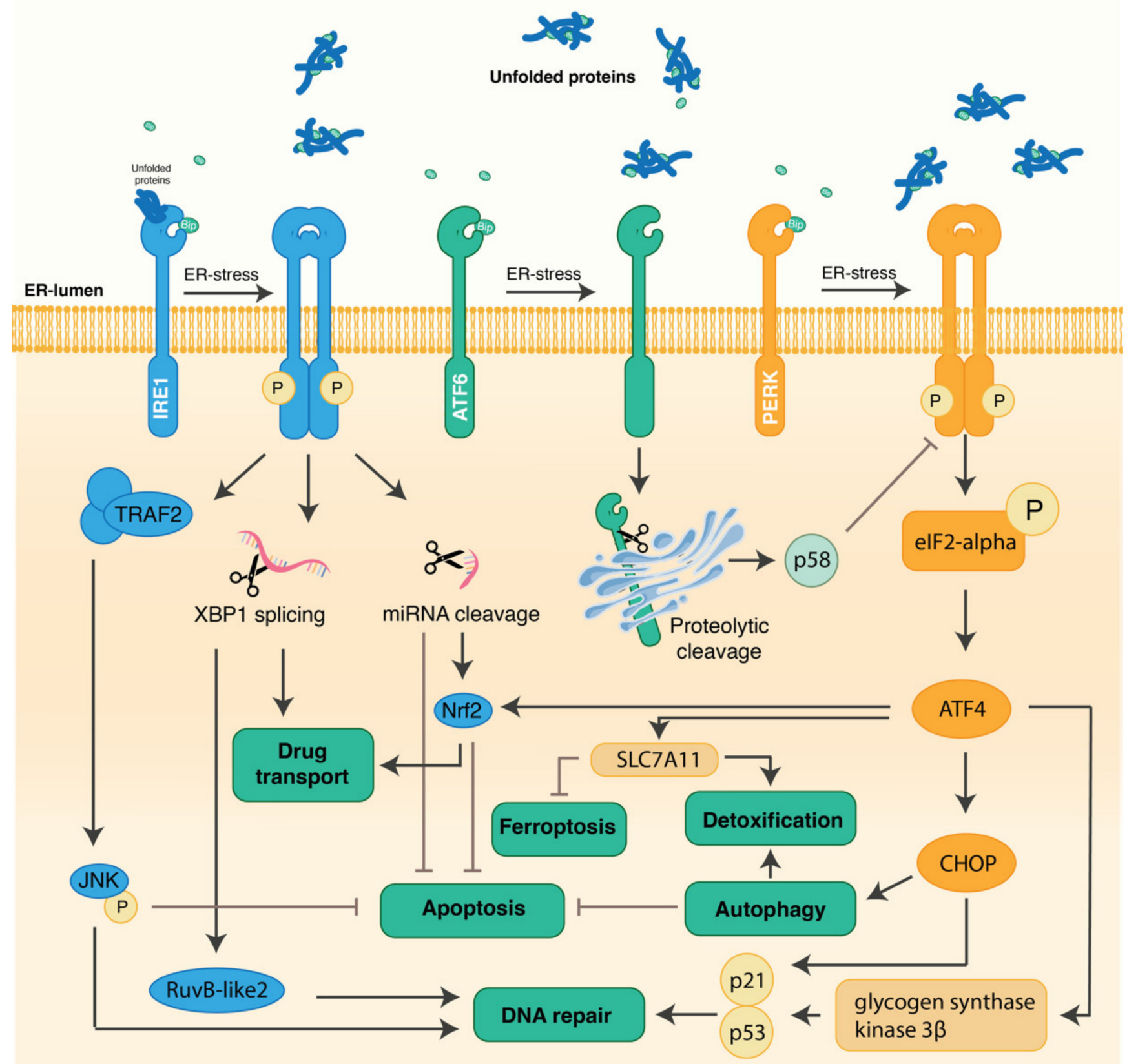

Figure 2. The accumulation of unfolded proteins in the endoplasmic reticulum lumen induces ER stress, leading to the dissociation of BiP from IRE1 $\alpha$, ATF6, and PERK. This activates the three pathways, resulting in the unfolded protein response, which in turns stimulates many underlying pathways and mechanisms that contribute to increased chemotherapeutic resistance in HCC. IRE1 $\alpha$ mainly leads to DNA repair and inhibition of apoptosis trough the activation of the TRAF2/JNK pathway, but also the alteration of drug transport through XBP1 splicing and Nrf2 activation. ATF6 on its turn activates p58 via proteolytic cleavage. Finally, PERK is mainly responsible for the mechanisms activating autophagy through the eif2-alpha/ATF4/CHOP axis and DNA repair (eif2-alpha/ATF4 pathway). It also inhibits ferroptosis via the eif2-alpha/ATF4 pathway. 


\subsection{Reduction of Drug Uptake and Enhanced Efflux}

Reduction of drug uptake is a key mechanism known to cause cellular resistance of tumor cells against chemotherapeutic agents in different solid tumors [28]. Elevated expression of transport proteins expressed at the plasma membrane limits intracellular accumulation of anti-cancer drugs, either by pumping agents out of the tumor cells (enhanced efflux) or by blocking their uptake (reduced influx) [14]. The majority of these proteins belong to the mammalian adenosine triphosphate (ATP)-binding cassette (ABC) family of transporters. There are 48 types of functionally diverse human transporters, which have been divided into 7 distinct subfamilies (A-G) on the basis of their structural relatedness and domain organization [29]. Thus far, 16 types of $A B C$ transporters are directly and/or indirectly linked to multidrug resistance in liver, kidney, pancreas, and other types of cancer (Table 1) [30-32]. The most extensively studied ABC transporters are the ABCB1 (permeability glycoprotein/MDR1), ABCC1 (multidrug resistance-associated protein-1, MRP1), and ABCG2 (breast cancer resistance protein (BCRP)) [32]. Their main ability is to recognize chemotherapeutic agents after their internalization within the plasma membrane and use the energy produced via ATP hydrolysis in order to expel drug molecules out of the cells, thereby decreasing bioavailability and increasing drug resistance $[29,33]$. Transportation of drugs across cells occurs through multiple processes, such as passive diffusion, facilitated or active transport, or pinocytosis. A major barrier that prevents drugs from accessing intracellular partitions in the plasma membrane is the solute carrier (SLC) family of proteins, which encode both passive and ion coupled carriers, as well as exchangers, which regulate 360 uptake carriers in the cell membrane [15]. Downregulation or inhibition of transporters may cause resistance to therapy due to reduced drug uptake or early/late impairment of endocytic pathways $[14,34]$.

One of the most common drug resistance mechanisms in HCC is enhanced drug efflux through induction of ABC cassette transporters, such as MDR1, MRP1, and MRP2 [22,35,36]. Previous studies have shown that activation of ER stress pathways, specifically PERK and IRE1 $\alpha$, are important inducers of ABC transporter expression [23]. When it comes to PERK, Salaroglio et al. demonstrated through gene profiling analysis that high levels of PERK are found in human colon cancer cells resistant to chemotherapy [37]. This study further exposes that PERK forms an axis with nuclear receptor and transcription factor Nrf2, which was shown to directly regulate transcription of MRP1 [37]. In addition, this Nrf2/SHH signaling cascade is known to promote drug resistance in several HCC cell lines [35,38], as Nrf2 activity upregulates multidrug-resistant efflux pumps [35,39,40]. In addition, Nrf2 has also been identified as a transcription substrate of PERK, thus further strengthening the interaction between Nrf2 expression and ER stress signaling [41]. The ATF4/PERK pathway also interacts with the long non-coding RNA (lncRNA) ZFAS1 signaling pathway, which has been shown to be important in sorafenib resistance [42]. Sorafenib itself may contribute to ZFAS1 activation by activating PERK/ATF4-pathways in drug-resistant HCC cells and inhibiting the PERK-signaling pathway, which has been suggested to re-sensitize cells to sorafenib [42]. This suggests that specific PERK inhibitors could provide an attractive therapeutic target to enhance efficacy of sorafenib treatment in HCC [42]. The strong link between PERK and drug response has led to several studies using PERK inhibitors in preclinical studies; however, careful evaluation is warranted, as there have been critical issues with specificity of some of these inhibitors [43]. 
Table 1. ATP-binding cassette ABC efflux pumps involved in enhanced drug efflux and reduced drug uptake stratified according to their TMD folds.

\begin{tabular}{|c|c|c|c|c|}
\hline TMD Fold & Subfamily & Gene & Function & Upregulation in Cancer \\
\hline \multirow{12}{*}{ Type IV } & \multirow{3}{*}{$\mathrm{ABCB}$} & $\begin{array}{l}\text { ABCB1 } \\
(P-g p)\end{array}$ & $\begin{array}{l}\text { Drug efflux and regulator of lipids and } \\
\text { steroids homeostasis in } \\
\text { central and peripheral nervous system }\end{array}$ & $\begin{array}{l}\text { Adrenocortical, breast, colorectal, } \\
\text { leukemic, ovarian, and renal cancers }\end{array}$ \\
\hline & & ABCB5 & GSH mediator & $\begin{array}{l}\text { Leukemic, lung, melanoma, ovarian, } \\
\text { renal, and thyroidal cancers }\end{array}$ \\
\hline & & ABCB8 & $\begin{array}{l}\text { Iron metabolism and homeostasis, } \\
\text { OS protection }\end{array}$ & $\begin{array}{l}\text { Head and neck, } \\
\text { pancreatic, and } \\
\text { renal cancers }\end{array}$ \\
\hline & \multirow{9}{*}{$\mathrm{ABCC}$} & $\begin{array}{l}\mathrm{ABCC} 1 \\
(\mathrm{MRP} 1)\end{array}$ & $\begin{array}{l}\text { Organic anion transporter and GSH } \\
\text { mediator }\end{array}$ & $\begin{array}{l}\text { Breast, endometrium, glioma, head } \\
\text { and neck, lung, lymphoma, } \\
\text { melanoma, ovarian, prostate, } \\
\text { neuroblastoma, and thyroid cancers }\end{array}$ \\
\hline & & $\mathrm{ABCC} 2$ & Organic anion transporter & $\begin{array}{l}\text { Colorectal, gastric, hepatic, and lung } \\
\text { cancers }\end{array}$ \\
\hline & & ABCC3 & Organic anion transporter & $\begin{array}{l}\text { Breast, cervical, colorectal, gastric, } \\
\text { hepatic, lung, ovarian pancreatic, } \\
\text { renal, and thyroid cancers }\end{array}$ \\
\hline & & $\mathrm{ABCC} 4$ & Nucleoside transporter & $\begin{array}{l}\text { Breast, endometrial, gastric, head and } \\
\text { neck, } \\
\text { hepatic, lung, neuroblastoma, ovarian, } \\
\text { prostate, andrenal cancers }\end{array}$ \\
\hline & & ABCC5 & Nucleoside transporter & $\begin{array}{c}\text { Breast, cervical, glioma hepatic, lung, } \\
\text { pancreatic, renal, and urothelial } \\
\text { cancers }\end{array}$ \\
\hline & & ABCC6 & $\begin{array}{l}\text { Putative biomineralization } \\
\text { modulator }\end{array}$ & Liver cancer \\
\hline & & $\mathrm{ABCC} 10$ & $\mathrm{E}(2) 17 \beta \mathrm{G}$ transporter & $\begin{array}{l}\text { Breast, colorectal, liver, lung, and } \\
\text { prostate cancers }\end{array}$ \\
\hline & & ABCC11 & Bile salts transporter & Breast cancer \\
\hline & & $\mathrm{ABCC} 12$ & Unknown & $\begin{array}{c}\text { Breast, colorectal, liver, lung, and } \\
\text { prostate cancers }\end{array}$ \\
\hline \multirow{3}{*}{ Type V } & ABCG & ABCG2 & Toxin efflux, cell differentiation & $\begin{array}{l}\text { Cervical, glioma, liver, ovarian, } \\
\text { prostate, pulmonary, renal, and } \\
\text { testicular cancers }\end{array}$ \\
\hline & \multirow[t]{2}{*}{$\mathrm{ABCA}$} & $\mathrm{ABCA} 2$ & Lipid transporter & $\begin{array}{c}\text { Breast, colon, leukemia, and liver } \\
\text { cancers }\end{array}$ \\
\hline & & ABCA8 & Lipophilic drugs transporter & Ovarian cancer \\
\hline- & $\mathrm{ABCF}$ & ABCF2 & Inflammatory development & Breast cancer \\
\hline
\end{tabular}

Although IRE1 $\alpha$ 's relationship to ABC transporters has not been clearly established in HCC, Gao et al. (2020) found that the IRE1 $\alpha-X B P 1$ axis participates in activating efflux pumps ABCC1 and ABCG2 in colon cancer cells resistant to 5-fluorouracil [44]. Treatment with 5-fluorouracil induces activation of IRE1 $\alpha-X B P 1$ and increases expression of $\mathrm{ABC}$ transporters. However, further research is necessary to clarify the role of IRE $1 \alpha$ and its relationship to enhanced drug efflux in HCC. One important aspect of IRE1 $\alpha^{\prime} \mathrm{s}$ endoribonuclease activity is that this is not only responsible for cleaving XBP1, but several studies have shown that IRE1 $\alpha$ is also able to cleave and regulate miRNAs [45-47]. ER stress has therefore been shown to contribute to the miRNA imbalance in inflammation [47] and cancer [48]. This could be particularly interesting in the context of drug resistance, 
as Shi et al. has previously shown that upregulation of miRNAs may confer resistance to 5-fluorouracil in HCC cell lines [49]. Through a CCK-8 assay, researchers found that ectopic expression of MiR-141 can directly induce chemoresistance in HepG2, SMMC-7721, and Huh7 cell lines [49]. Moreover, MiR-141 facilitates Nrf2 pathway activation by targeting Kelch-like ECH-associated protein (Keap1), which under healthy conditions mediates ubiquitination and degradation of Nrf2. Thus, Shi et al. (2015) further demonstrated that MiR-141 deregulates Keap1 protein stability, thereby inducing Nrf2, which may in turn result in overexpression of $\mathrm{ABC}$ cassette transporters [49]. On the other hand, miR-122 specifically targets the membrane transporter SLC7A1, which is associated with resistance to sorafenib. miR-122 upregulation can potentially knock down SLC7A1 expression and re-sensitize HCC cells to sorafenib treatment [50]. On the basis of previous results, ER stress seems to act as a regulator of miRNAs, which could potentially influence drug response through different mechanisms that involve either drug efflux (such as miR-131) or drug uptake (such as miR-122). However, further research is necessary to identify the exact pathways that could be relevant in HCC and underlying mechanisms that regulate these miRNAs, as well as their target genes.

The PERK/ATF4 branch of the ER stress pathways has also been implicated in drug uptake. Gao et al. uncovered that YAP/TAZ transcription factors play a crucial role in sorafenib resistance in HCC by inducing SLC7A11 expression, which is a core carrier that sustains intracellular glutathione homeostasis [51]. This allows HCC cells to overturn sorafenib-induced ferroptosis. Simultaneously, protein stability, nuclear localization, and transcriptional activity of ATF4 is upheld by YAP/TAZ activation. In turn, ATF4 also collaborates with YAP/TAZ to activate SLC7A11 expression, thus further enhancing drug transport over the cellular membrane. Hence, YAP/TAZ represses ferroptosis and consequently contributes to sorafenib resistance in HCC in an ATF4-dependent manner. This further underlines the potential value of rewiring approaches that rely on ATF4 and YAP/TAZ activation as a means to counter chemotherapeutic resistance in HCC [51].

\subsection{Alteration of the Drug Targets}

Many anti-cancer drugs must undergo metabolic activation to exert their cytotoxic effects. Cancer cells can therefore develop resistance by altering expression of specific enzymes involved in drug metabolism. One such example is DNA topoisomerase, which is a family of nuclear enzymes that regulate DNA topology and is recognized as the primary targets of chemotherapeutic drugs, including anthracyclines (e.g., doxorubicin) [52]. Activation of the UPR has been shown to reduce topoisomerase II $\alpha$ protein levels [53] and thereby decrease sensitivity to topoisomerase-targeted drugs, such as doxorubicin [54]. In addition, exposure of cells to etoposide, a topoisomerase II inhibitor, triggers mild IRE1 $\alpha$ phosphorylation, without triggering other pathways of ER stress [55], which further suggests an interaction between ER stress signaling pathways and potential alteration of drug targets. However, other studies have argued that activation of the PERK branch of the UPR is the major contributor to UPR-induced etoposide resistance, regardless of changes in topoisomerase II $\alpha$ protein expression [56]. Therefore, more research is necessary to confirm whether the UPR-induced decrease in topoisomerase II $\alpha$ is responsible for increased resistance to chemotherapeutics in HCC, or whether this is a result of another ER stress-dependent drug resistance mechanism.

\subsection{Induction of Drug-Detoxifying Mechanisms}

Drug inactivation can play a major role in the development of resistance to chemotherapeutic drugs. This can be achieved, for example, through conjugation of chemotherapeutic drugs to glutathione by glutathione S-transferases [56]. Studies have shown that autophagy can increase expression of glutathione transferases, thereby directly contributing to chemoresistance [57]. Autophagy is an intracellular lysosome-mediated degradation pathway used for recycling and eliminating proteins and protein aggregates, an essential protective mechanism that is activated during ER stress [58]. Both ER stress and autophagy 
systems are dynamically interconnected, with ER stress pathways both stimulating or inhibiting autophagy. Autophagy protects cancer cells from chemotherapy by repressing apoptotic signals, as well as by triggering activation of glutathione transferases. These enzymes are involved in catalyzing nucleophilic addition of glutathione to chemicals with an electrophilic functional group (including products of oxidative stress, as well as directly binding to chemotherapeutic agents) [59]. Autophagy in HCC can thereby contribute to tolerance of chemotherapeutic drugs, such as oxaliplatin, via regulation of ROS levels or by direct glutathione conjugation. One study specifically showed that knockdown of glutathione transferase mu-1 in MHCC $97-\mathrm{H}$ and Huh-7 cells increases resistance to oxaliplatin and sorafenib, as well as the fact that oxaliplatin-induced autophagy can be downregulated by silencing this enzyme [57]. Furthermore, Shi et al. demonstrated that sorafenib exposure in HCC cells upregulates IRE1 $\alpha$ pathway signaling, thereby inducing autophagy [60]. This study also revealed that when autophagy was suppressed, HCC cells were re-sensitized to ER stress-induced cell death, both in in vitro as well as in in vivo studies [60]. These findings underline the role of sorafenib-related ER stress in triggering autophagy, which could be directly or indirectly related to the activation of glutathione transferases [60]. There have also been studies showing a potential direct link between ER stress pathways and glutathione transferases, which could contribute to drug-detoxifying mechanisms in drug resistant tumors. For instance, glutathione S-transferase P-mediated S-glutathionylation has been indicated to regulate activities of a number of redox-active ER proteins, including ER stress chaperone BiP [61]. The S-glutathionylation of $\mathrm{BiP}$ has then been proposed to contribute to bortezomib resistance in multiple myeloma cells [61]; however, more research is necessary to confirm this in HCC.

As mentioned previously, a recent study by Gao et al. showed that ATF4 induces activation of solute carrier SLC7A11, a cystine importer that plays a central role in the synthesis of glutathione [51]. Glutathione synthesis participates in suppression of ferroptosis and apoptosis in HCC cell lines in order to achieve cellular homeostasis. Moreover, nuclear import of ATF4 was found to be regulated and stabilized by YAP and TAZ transcription factors. In fact, YAP/TAZ and ATF4 proteins jointly trigger genes associated with antioxidant mechanisms, including SLC7A11 [51]. Antioxidant mechanisms may hamper efficacy of chemotherapy by scavenging ROS and free radicals, which are known to directly contribute to cytotoxic effects of many chemotherapeutics, including doxorubicin [62]. Recent studies have suggested a link between activation of the IRE1 $\alpha$ pathway and generation of ROS, thus further suggesting that drug-detoxifying mechanisms could contribute to an ER stress-dependent effect on drug resistance [22].

\subsection{Repair Mechanisms}

The majority of chemotherapeutics contain DNA-damaging reagents, which means tumor cells are able to develop resistance against chemotherapy by repairing DNA damage [63]. DNA damage response (DDR) is a complex signal transduction pathway that is able to repair various endogenous and exogenous DNA lesions that accumulate in cells $[64,65]$. Phosphorylation, ubiquitination, and sumoylation are part of the critical post-translational alterations that occur on DNA damage response genes, the latter being necessary for proper repair [66]. Although DNA repair protein impairment usually leads to apoptosis, cells may also experience genomic degradation according to the degree of damage [65]. Several genes have been reported to regulate DNA damage and repair in HCC, such as mitogen-activated protein kinase-extracellular signal-regulated kinase (MAPK-ERK), BRCA, p53, c-MYC, and interleukin-6 (IL-6), thus leading to intensive recovery from chemotherapy-induced DNA damage and thereby conferring resistance to tumor cells $[63,67,68]$.

Oshi et al. found that activation of BRCA1 and BRCA2 was correlated with a high DNA repair score in HCC, which was also related to poor survival, increased cell proliferation, high intra-tumoral heterogeneity, and mutational burden [63]. RuvB-like2, which is involved in DNA damage detection and repair, enhances cell proliferation and is overex- 
pressed in HCC, leading to a poor prognosis [63]. This gene was also shown to be closely related to the ER stress degradation (ERAD) mechanism by negatively mediating ER stress response proteins [69].

P53 is a tumor suppressor gene that plays an essential role in regulating cell cycle arrest, DNA-repair, and apoptosis as a result of DNA damage. It facilitates DNA repair by pausing the cell cycle, thereby allowing time for repair machineries to restore stability [70]. In addition, p53 takes on diverse roles that directly impact activity of various DNA repair systems [71]. Activation of p53 is tightly regulated by a complex web of pathways that control its post-translational modification, sub-cellular localization, and degradation [64,71]. Although the UPR has been suggested as an essential player in regulating p53 [72], the exact mechanism is not fully understood, since ER stress can both activate [73] or destabilize p53 [74,75]. Activation of p53 during ER stress was mainly associated with increased apoptotic cell death acting through NF- $\mathrm{B}$ B signaling pathways [73]. However, other studies have shown that p53 adopts a mostly cytoplasmic distribution during ER stress, suggesting an inhibition of its function [74]. The UPR regulates glycogen synthase kinase $3 \beta$, which is essential for regulating p53 and cyclin D1 degradation in the event of early ER stress [74]. Further studies have suggested that ER stress induces destabilization of p53 and therefore prevents cells from p53-dependent apoptosis, which could form an important mechanism of resistance to chemotherapy [75]. This is mediated, at least in part, through increased cytoplasmic localization of p53 as a result of phosphorylation at serines 315 and 376 by increased activity of glycogen synthase- $3 \beta$. Although molecular mechanisms remain largely unknown, BiP's mRNA is also known to interact with p53. This interaction results in inhibition of $\mathrm{BiP}$ protein synthesis and leads to a decreased interaction between $\mathrm{BiP}$ and Bcl-2-interacting killer protein, a pro-apoptotic member of the Bcl-2 family [76]. The downstream target of p53, namely, p21, has further been shown to be regulated by PERK [77] and CHOP [78]. In addition, p21 induction is thought to play an important role in the response to ER stress, as p21 is a pro-survival effector of ATF4 [79]. The above-mentioned results on the role of p53 during ER stress focus on the full-length p53 protein without addressing the expression of its isoforms. These isoforms exist to facilitate the protein's response to different stimuli, as they can modulate activity of the full-length protein or affect different pathways [80]. One of these p53 isoforms is p47, whose expression is specifically induced by PERK during ER stress [81]. Overall, these different studies suggest a tight link between p53, ER stress, and DNA repair mechanisms that needs to be further elucidated to truly understand its role in mediating drug resistance in HCC.

The MAPK signaling pathway has also been reported to contribute to DNA repair in HCC [63]. MAPK signaling pathways are activated in response to extracellular signals, such as growth factors, cytokines, and ER stress [4]. The UPR promotes ASK1-MKK4/7JNK expression and also induces ERK1/2 activity. Nonetheless, MEKK4-MKK3/4/6-p38 signaling also regulates UPR through CHOP and ATF6 p38-related phosphorylation. IRE1 $\alpha$ has been shown to induce JNK and ERK1/2 and modulate the oligomerisation of TRAF2, which in turn can trigger the ASK1-MKK4/7-JNK-pathway [82], thereby suggesting an important role of ER stress in inducing MAPK-dependent DNA repair mechanism, which could then contribute to drug resistance.

\subsection{Insensitivity to Drug-Induced Cell Death}

Another important mechanism that contributes to drug resistance is inhibition of cell death. Expression of prognostic ER stress proteins such as GADD34, eIF2 $\alpha, \mathrm{CHOP}$, and ATF4, being regulated by PERK, were shown to be involved in apoptosis, as well as in chemo-responsiveness [37,83]. Meanwhile regarding ferroptosis, another type of cell death [84], recent studies have shown there is a cross-talk between ER stress and the lipidome that mediates chemoresistance when responding to anthracyclines, such as doxorubicin and idarubicin [18]. The lipid membrane composition was established to be the main factor affecting drug fluidity and membrane permeability. In addition, lipid membrane structure also shapes activation of drug transporter-regulated efflux mechanisms 
related to multidrug resistance [85]. Therefore, the study suggests that in the interconnection between ER stress pathways and the lipidome, there is an overall shift in the balance among various lipid types, which is associated with ER stress [18]. For example, the imbalance of PUFA-containing lipids in comparison to saturated lipids and cholesterol contributes to ER stress, which can result in the repression of apoptosis and ferroptosis [18].

Furthermore, ER stress receptor of activated protein kinase (RACK1) was found to be critical in inducing IRE1 $\alpha$ signaling response to sorafenib in HCC cells [86]. Although IRE1 $\alpha$ activation was shown to favorize ER stress-induced apoptosis via JNK, RACK1 dysregulation was found to be responsible for IRE1 $\alpha$ 's high phosphorylation, thereby promoting XBP1 splicing and preventing sorafenib-induced cell death [23]. Indeed, overexpressed RACK1 was shown to prevent apoptotic action of sorafenib in HCC cells by upregulating XBP1, which consequently decreased when RACK1 was depleted [86]. Both RACK1 and IRE1 were found to be intercellularly interacting and were co-located in the cytoplasm. Silencing of RACK1 strongly inhibited IRE1 phosphorylation following treatment with either tunicamycin or sorafenib, which resulted in UPR suppression. According to the findings of Zhou et al., there is a crosstalk between RACK1 and IRE1, suggesting that they cooperate to regulate IRE1 signaling activity in response to sorafenib-dependent UPR activation, which in turn controls ER-mediated cell death following treatment [86].

In addition, as previously mentioned, PERK is responsible for regulating Nrf2 [41], which besides activating ABC transporter efflux pumps [39], has also been reported to promote anti-apoptotic signals [87]. The role of Nrf2 in blocking cell death was confirmed as inhibition of Nrf2 restored sensitivity to apoptosis and reversed chemoresistance in Bel-7402/5-FU cell lines [88]. It was further established that miR-144 is responsible for Nrf2 mRNA degradation by directly targeting the Nrf2 3'untranslated region in chemo-sensitive HCC cells and the fact that resistant cell lines were characterized by a dramatic loss of miR-144 [88]. In an effort to further examine the influence of Nrf2 on cell death, another study suggests that its elicitation might be related to mitochondrial DNA depletion in HCC cell lines [89]. It has been previously demonstrated that there is an underlying relationship between mtDNA and ER stress, suggesting that any disturbance in the ER could have an impact on mtDNA and vice versa [90-92]. Investigating the crosstalk between ER stress and mtDNA depletion could then provide precious insights to further assess chemoresistance mechanisms in HCC in relation to cell death [92], especially as mtDNA depletion was also found to trigger other markers such as survivin, Bax, and Bcl2, which, when imbalanced, hinder pro-apoptotic signals [89].

Other studies suggest that IRE1 $\alpha$ and PERK can induce STAT3 and NFkB [93-95], which are known to transcriptionally overexpress cell death-inhibiting proteins, such as $\mathrm{Bcl} 2$, caspase-8 inhibitor c-FLIP, MCL1, and IAP [96,97]. Another possibility is activation of transcription factor ATF6, which is also shown to confer chemoresistance in HCC cell lines by impeding ER stress-induced cell death and promoting cell survival [98]. ATF6 was observed to form an axis with protein disulfide isomerase P58 [99], thereby restricting cell death under oncogenic transformation, by suppressing the PERK-CHOP pro-apoptotic pathway [21]. At the same time, PERK has been shown to contribute to synthesis of eIF2 $\alpha$, which supports cancer cell survival. Therefore, CHOP has been identified as a promoter of hepatocarcinogenesis [100,101], despite its well-established pro-apoptotic function in physiological conditions [102].

Moreover, as mentioned earlier, an intrinsic link between ER stress and miRNAs has been suggested [48]. Addressing this deregulation in depth, research found that in addition to triggering $\mathrm{ABC}$ transporters, over-expression of miR-141 blocked cytotoxic and apoptotic activity of 5-fluorouracil in several HCC cell lines [49,88]. In parallel, when miR-141 was knocked down, cells regained susceptibility to apoptosis triggered by 5-fluorouracil. MiR-141 would therefore have the capacity to confer chemoresistance to cancer cells by disrupting their sensitivity to 5-fluorouracil-induced cell death [49]. This further displays the interconnection between ER stress, miRNA, and cell death that could contribute to chemoresistance in HCC. 


\section{Role of the Tumor Microenvironment}

The tumor microenvironment is composed of cancer and stromal cells, surrounded by vast amounts of extracellular matrix proteins, and characterized by an abnormal and dysfunctional vasculature. This tumor microenvironment is not a passive bystander in the hepatocarcinogenic process but actively fuels and regulates tumor progression, metastasis, and drug response [6].

Tumor hypoperfusion, hyperpermeability, and leakiness of the abnormal tumoral vasculature, along with hypoxia, nutrient deprivation, acidic conditions, and high interstitial pressure, can contribute to reduced response to chemotherapeutics. In addition, these are all common triggers of the UPR (Figure 3) [6,103-105]. Hypoxia has been shown to induce resistance to sorafenib, cisplatin, 5-fluorouracil, gemcitabine, adriamycin, and 6thioguanine in several HCC cell lines [106]. Furthermore, hypoxia and nutrient deprivation are strong independent UPR inducers by upregulating GRP78/BiP expression levels [107]. It has been shown that knocking down GRP78/BiP with short hairpin RNA can improve response to cisplatin treatment under severely hypoxic conditions [107]. These results indicate a clear link between ER stress signaling, hypoxia, and drug response, yet more research is necessary to confirm this in HCC.

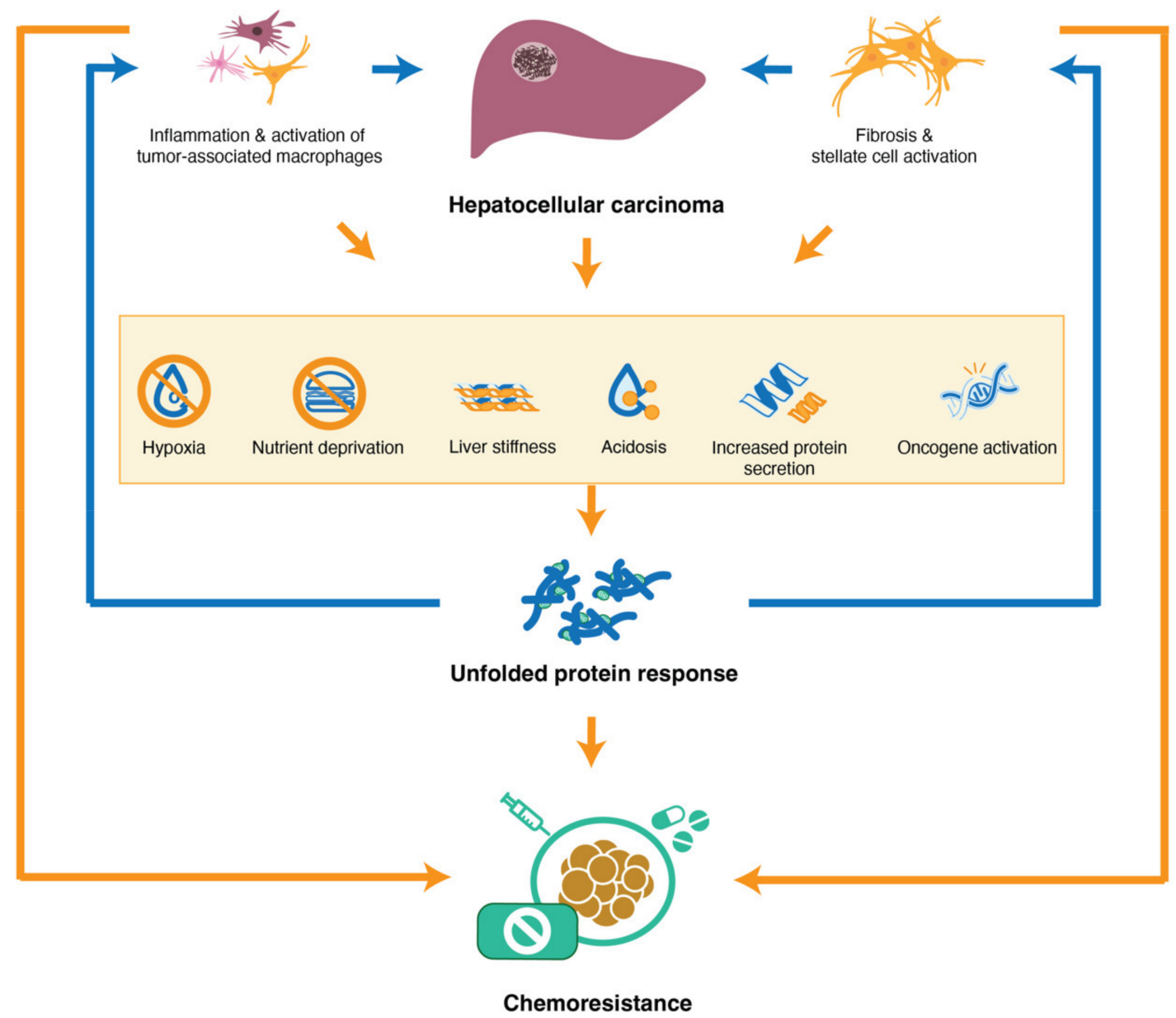

Figure 3. Tumor hypoperfusion, along with low oxygen levels, depleted nutrition, low $\mathrm{pH}$ (acidosis), increased liver stiffness, and an overall increased need for protein translation by rapidly proliferating tumor cells and recruitment of inflammatory cells, as well as activation of oncogenes, all induce the UPR inside tumor cells and in its microenvironment. This activation of the UPR will amplify the pro-tumoral inflammatory response and further increase activation of stellate cells, leading to fibrosis and deposition of ECM, thus inducing a vicious circle that further fuels ER stress pathways and contributes directly and indirectly to increased chemoresistance in HCC. 
Sustained liver damage and chronic inflammation leads to activation of hepatic stellate cells, which increases deposition of extracellular matrix proteins, such as collagen and fibrinogen. The abundance of extracellular matrix proteins increases liver stiffness, thereby altering bio-mechanical properties and inducing mechanical stress in different hepatic cell populations [108]. The increased stiffness of a cirrhotic liver also leads to hypoxia, acidosis, nutrient deprivation, altered bio-mechanical properties, and generation of ROS, which can all directly induce the UPR [109]. It is therefore not surprising that increased liver stiffness has been correlated with decreased drug response of HCC cells embedded in a 3D matrix consisting of collagen and/or fibrinogen [110,111]. However, whether this is a result of an increased activation of the UPR still needs to be confirmed.

Cancer-associated fibroblasts (CAFs) and activated stellate cells are key players in tumor-stroma interactions and are major mediators in carcinogenesis, tumor progression, and chemoresistance [112,113]. Studies have shown that ER stress plays a crucial role in activation of hepatic stellate cells $[114,115]$ and that blocking the IRE1 $\alpha-X B P 1$ pathway can significantly reduce liver fibrosis and tumor burden in several animal models for cirrhosis [47] and HCC [22]. Jia et al. sought to provide a deeper investigation regarding the involvement of CAFs in epithelial-mesenchymal transition (EMT) in HCC [116], a process that is known to contribute to drug resistance in HCC and many other solid tumors $[117,118]$. Proteomic analyses identified that transglutaminase 2 (TG2) is substantially overexpressed in HCC cells that have obtained an EMT phenotype. Increased TG2 activity supported EMT in HCC cells, while TG2 depletion significantly decreased CAF-induced EMT [116]. Moreover, TG2 activity was improved once HCC cells were triggered by IL-6 during EMT, and suppressing IL-6/STAT3 signaling lowered TG2 activity. Consequently, H-CAFs promote EMT in HCC cells mediated by IL-6, activating the IL-6/IL6R/STAT3 pathway and thereby inducing TG2 [116]. As ER stress is an important factor in activating CAFs and stellate cells, it could therefore be proposed that this would then contribute to an increased drug resistance through CAF-induced EMT.

Another major component of the tumor microenvironment are tumor-associated macrophages, which play a pivotal role HCC $[119,120]$. Macrophages are heterogeneous by nature, as they actively engage in both induction and resolution of inflammation. The ability of macrophages to be reprogrammed is an active area of research, especially in HCC, where they have been reported to play a dual role in promoting or inhibiting tumor progression, depending on their polarization state. Firstly, classically activated macrophages, which develop a proinflammatory Th1 immune response and exert an anti-tumoral activity. Secondly, alternatively activated macrophages, or tumor-associated macrophages (TAM), which display an anti-inflammatory Th2 immune response and exert a tumor-promoting activity. The balance between these anti-tumoral and pro-tumoral macrophages has a significant impact on determining the response to chemotherapy. For instance, studies have shown that TAMs modulate resistance to oxaliplatin by inducing autophagy in HCC cells [121]. In addition, actors of ER stress pathways have been shown to play an important role in regulating the polarization state of hepatic macrophages [122]. Studies have shown that activation of ER stress pathways is associated with an increased anti-tumoral and pro-inflammatory phenotype, mainly through activation of PERK and CHOP [122-124]. By mediating the macrophage's polarization state and function, the UPR could therefore influence chemotherapeutic response in HCC. Furthermore, studies have shown that IRE1 $\alpha$ mediates release of inflammatory extracellular vesicles by hepatocytes in mouse models for non-alcoholic steatohepatitis [125]. It remains to be elucidated as to whether this also affects the inflammatory response in HCC and contributes to alterations in drug response.

However, it has become increasingly clear that UPR signaling plays an important role in immunity and inflammation. The three different arms of the UPR pathways have been involved in activating different inflammatory cell types, including tumor-associated macrophages, monocytes, dendritic cells, and tumor-associated neutrophils [126]. The latter also play an important role in orchestrating drug resistance in HCC [127]. Interestingly, a recent study demonstrated that neutrophils can drive PERK-mediated apoptosis in cancer 
cells through secretion of arginase-1 [128]. The neutrophil's secreted arginase will lead to arginine deprivation in cancer cells, thereby inducing ER stress and resulting in apoptosis of tumor cells. In addition, as different inflammatory cell populations become activated during liver damage, they are known to generate large amounts of growth factors, which in itself can contribute to therapeutic resistance. In resistant HCC cells, enhanced autocrine generation of growth factors, such as interleukin (IL)-1, IL-4, IL-6, and IL-8, was observed in comparison to tumor cells responsive to treatment $[129,130]$. The IRE1 $\alpha-X B P 1$ pathway was found to mediate IL-6 expression and subsequently support tumor cell proliferation in HCC [131]. In human HCC tissues and cells, XBP1 splicing levels and IL-6 concentrations were elevated and favorably correlated to one another [131]. Furthermore, secretory levels and expression of IL- 6 were lowered after pharmacological inhibition of IRE1 $\alpha$ 's splicing activity, thereby hindering XBP1s direct binding to IL- 6 and limiting expression of this interleukin. The enhancing effect of IRE1 $\alpha-X B P 1$ signaling in Hep3B cell proliferation was alleviated through inhibition of IL-6-STAT3 signaling by tocilizumab. As a result, by mediating activation of the IL-6-STAT3 signaling pathway, the IRE1 $\alpha-$ XBP1 axis was shown to play a critical role in HCC carcinogenesis [131].

\section{Discussion}

Hepatocellular carcinoma (HCC) is one of the most common and deadly cancers worldwide. It is usually diagnosed in an advanced stage and is characterized by a high intrinsic drug resistance leading to limited chemotherapeutic efficacy [13,16]. There is therefore a vast need for understanding underlying mechanisms that contribute to drug resistance and for developing therapeutic strategies that could overcome this process [132]. One important mechanism that contributes to drug resistance is activation of endoplasmic reticulum (ER) stress pathways, which then leads to induction of the unfolded protein response (UPR) [10,21,37]. The UPR is a conserved cell survival strategy and stress response, initiated when a cell's need for protein synthesis exceeds the ER's capacity to ensure accurate protein folding [12,21,92]. In such cases, accumulation of misfolded or unfolded proteins, known as ER stress, is sensed through three ER transmembrane proteins (IRE1 $\alpha$, PERK, ATF6), which activate the UPR with the goal of re-establishing normal ER function or inducing apoptosis. Actors of the UPR pathways are activated in the majority of cancers [133], and their expression has been correlated with poor prognosis in HCC [22,23], as well as decreased response to chemotherapeutics [10]. Tumor cells obtain resistance to chemotherapeutics mainly through five different mechanisms: reduction of drug uptake, alteration of the drug targets, induction of drug-detoxifying mechanisms, repair of druginduced damages, and insensitivity to drug-induced cell death $[16,28,65]$. In addition, the tumor microenvironment has also been shown to play a pivotal role in determining response to chemotherapeutics. In this review, we highlighted how the three arms of the UPR are highly connected to the different mechanisms that contribute to chemoresistance in HCC.

Author Contributions: Conceptualization, F.H. and M.K.; resources F.H. and H.L.; writing-original draft preparation, J.K., M.K., and F.H.; writing-review and editing, J.K., F.H., M.K., and H.L.; visualization, J.K. and F.H.; supervision, F.H., M.K., and H.L.; project administration, F.H.; funding acquisition, F.H. and H.L. All authors have read and agreed to the published version of the manuscript.

Funding: This research was funded by The Swedish Cancer Foundation (Cancerfonden), grant numbers 20 1076PjF, 200175 F, and CAN2018/602; The Swedish Society for Medical Research (SSMF), grant number S17-0092; and The Swedish Research Council (Vetenskapsrådet), grant numbers 201803301 and 2020-02367.

Conflicts of Interest: The authors declare no conflict of interest. 


\section{References}

1. Yang, J.D.; Hainaut, P.; Gores, G.J.; Amadou, A.; Plymoth, A.; Roberts, L.R. A global view of hepatocellular carcinoma: Trends, risk, prevention and management. Nat. Rev. Gastroenterol. Hepatol. 2019, 16, 589-604. [CrossRef] [PubMed]

2. Mak, L.Y.; Cruz-Ramón, V.; Chinchilla-López, P.; Torres, H.A.; LoConte, N.K.; Rice, J.P.; Foxhall, L.E.; Sturgis, E.M.; Merrill, J.K.; Bailey, H.H.; et al. Global Epidemiology, Prevention, and Management of Hepatocellular Carcinoma. Am. Soc. Clin. Oncol. Educ. Book 2018, 38, 262-279. [CrossRef] [PubMed]

3. Zhang, C.; Yang, M. Current Options and Future Directions for NAFLD and NASH Treatment. Int. J. Mol. Sci. 2021, $22,7571$. [CrossRef] [PubMed]

4. Moon, H.; Ro, S.W. MAPK/ERK Signaling Pathway in Hepatocellular Carcinoma. Cancers 2021, 13, 3026. [CrossRef]

5. Zhang, Y.; Wang, H.; Xiao, H. Metformin Actions on the Liver: Protection Mechanisms Emerging in Hepatocytes and Immune Cells against NASH-Related HCC. Int. J. Mol. Sci. 2021, 22, 5016. [CrossRef]

6. Heindryckx, F.; Gerwins, P. Targeting the tumor stroma in hepatocellular carcinoma. World J. Hepatol. 2015, 7, 165-176. [CrossRef]

7. Pocha, C.; Xie, C. Hepatocellular carcinoma in alcoholic and non-alcoholic fatty liver disease-one of a kind or two different enemies? Transl. Gastroenterol. Hepatol. 2019, 4, 72. [CrossRef]

8. Hetz, C.; Zhang, K.; Kaufman, R.J. Mechanisms, regulation and functions of the unfolded protein response. Nat. Rev. Mol. Cell Biol. 2020, 21, 421-438. [CrossRef]

9. Walczak, A.; Gradzik, K.; Kabzinski, J.; Przybylowska-Sygut, K.; Majsterek, I. The Role of the ER-Induced UPR Pathway and the Efficacy of Its Inhibitors and Inducers in the Inhibition of Tumor Progression. Oxidative Med. Cell. Longev. 2019, 2019, 5729710. [CrossRef]

10. Al-Rawashdeh, F.Y.; Scriven, P.; Cameron, I.C.; Vergani, P.V.; Wyld, L. Unfolded protein response activation contributes to chemoresistance in hepatocellular carcinoma. Eur. J. Gastroenterol. Hepatol. 2010, 22, 1099-1105. [CrossRef]

11. Sovolyova, N.; Healy, S.; Samali, A.; Logue, S.E. Stressed to death-Mechanisms of ER stress-induced cell death. Biol. Chem. 2014, 395, 1-13. [CrossRef] [PubMed]

12. Riaz, T.A.; Junjappa, R.P.; Handigund, M.; Ferdous, J.; Kim, H.R.; Chae, H.J. Role of Endoplasmic Reticulum Stress Sensor IRE1alpha in Cellular Physiology, Calcium, ROS Signaling, and Metaflammation. Cells 2020, 9, 1160. [CrossRef] [PubMed]

13. Bao, M.H.; Wong, C.C. Hypoxia, Metabolic Reprogramming, and Drug Resistance in Liver Cancer. Cells 2021, 10, 1715. [CrossRef]

14. Bukowski, K.; Kciuk, M.; Kontek, R. Mechanisms of Multidrug Resistance in Cancer Chemotherapy. Int. J. Mol. Sci. 2020, 21, 3233. [CrossRef] [PubMed]

15. Duan, B.; Huang, C.; Bai, J.; Zhang, Y.L.; Wang, X.; Yang, J.; Li, J. Multidrug Resistance in Hepatocellular Carcinoma. In Hepatocellular Carcinoma; Tirnitz-Parker, J.E.E., Ed.; Codon Publications: Brisbane, Australia, 2019.

16. Marin, J.J.G.; Macias, R.I.R.; Monte, M.J.; Romero, M.R.; Asensio, M.; Sanchez-Martin, A.; Cives-Losada, C.; Temprano, A.G.; Espinosa-Escudero, R.; Reviejo, M.; et al. Molecular Bases of Drug Resistance in Hepatocellular Carcinoma. Cancers 2020, 12, 1663. [CrossRef] [PubMed]

17. Corazzari, M.; Gagliardi, M.; Fimia, G.M.; Piacentini, M. Endoplasmic Reticulum Stress, Unfolded Protein Response, and Cancer Cell Fate. Front. Oncol. 2017, 7, 78. [CrossRef]

18. Balgoma, D.; Kullenberg, F.; Calitz, C.; Kopsida, M.; Heindryckx, F.; Lennernas, H.; Hedeland, M. Anthracyclins Increase PUFAs: Potential Implications in ER Stress and Cell Death. Cells 2021, 10, 1163. [CrossRef]

19. Jin, T.; Lin, J.; Gong, Y.; Bi, X.; Hu, S.; Lv, Q.; Chen, J.; Li, X.; Chen, J.; Zhang, W.; et al. iPLA2beta Contributes to ER Stress-Induced Apoptosis during Myocardial Ischemia/Reperfusion Injury. Cells 2021, 10, 1446. [CrossRef]

20. Ghosh, R.; Wang, L.; Wang, E.S.; Perera, B.G.; Igbaria, A.; Morita, S.; Prado, K.; Thamsen, M.; Caswell, D.; Macias, H.; et al. Allosteric inhibition of the IRE1alpha RNase preserves cell viability and function during endoplasmic reticulum stress. Cell 2014, 158, 534-548. [CrossRef]

21. Cubillos-Ruiz, J.R.; Bettigole, S.E.; Glimcher, L.H. Tumorigenic and Immunosuppressive Effects of Endoplasmic Reticulum Stress in Cancer. Cell 2017, 168, 692-706. [CrossRef]

22. Pavlovic, N.; Calitz, C.; Thanapirom, K.; Mazza, G.; Rombouts, K.; Gerwins, P.; Heindryckx, F. Inhibiting IRE1alpha-endonuclease activity decreases tumor burden in a mouse model for hepatocellular carcinoma. eLife 2020, 9, e55865. [CrossRef] [PubMed]

23. Pavlovic, N.; Heindryckx, F. Exploring the Role of Endoplasmic Reticulum Stress in Hepatocellular Carcinoma through mining of the Human Protein Atlas. Biology 2021, 10, 640. [CrossRef] [PubMed]

24. Pavlovic, N.; Heindryckx, F. Targeting ER stress in the hepatic tumor microenvironment. FEBS J. 2021. [CrossRef] [PubMed]

25. Kokott-Vuong, A.; Jung, J.; Fehr, A.T.; Kirschfink, N.; Noristani, R.; Voigt, A.; Reich, A.; Schulz, J.B.; Huber, M.; Habib, P. Increased Post-Hypoxic Oxidative Stress and Activation of the PERK Branch of the UPR in Trap1-Deficient Drosophila melanogaster Is Abrogated by Metformin. Int. J. Mol. Sci. 2021, 22, 11586. [CrossRef]

26. Hou, J.; Zhang, H.; Sun, B.; Karin, M. The immunobiology of hepatocellular carcinoma in humans and mice: Basic concepts and therapeutic implications. J. Hepatol. 2020, 72, 167-182. [CrossRef]

27. Tacke, F. Targeting hepatic macrophages to treat liver diseases. J. Hepatol. 2017, 66, 1300-1312. [CrossRef]

28. Marin, J.J.G.; Perez-Silva, L.; Macias, R.I.R.; Asensio, M.; Peleteiro-Vigil, A.; Sanchez-Martin, A.; Cives-Losada, C.; SanchonSanchez, P.; Sanchez De Blas, B.; Herraez, E.; et al. Molecular Bases of Mechanisms Accounting for Drug Resistance in Gastric Adenocarcinoma. Cancers 2020, 12, 2116. [CrossRef] 
29. Khunweeraphong, N.; Kuchler, K. Multidrug Resistance in Mammals and Fungi-From MDR to PDR: A Rocky Road from Atomic Structures to Transport Mechanisms. Int. J. Mol. Sci. 2021, 22, 4806. [CrossRef]

30. Serra, M.; Hattinger, C.M.; Pasello, M.; Casotti, C.; Fantoni, L.; Riganti, C.; Manara, M.C. Impact of ABC Transporters in Osteosarcoma and Ewing's Sarcoma: Which Are Involved in Chemoresistance and Which Are Not? Cells 2021, $10,2461$. [CrossRef]

31. He, J.; Fortunati, E.; Liu, D.X.; Li, Y. Pleiotropic Roles of ABC Transporters in Breast Cancer. Int. J. Mol. Sci. 2021, 22, 3199. [CrossRef]

32. Juan-Carlos, P.M.; Perla-Lidia, P.P.; Stephanie-Talia, M.M.; Monica-Griselda, A.M.; Luz-Maria, T.E. ABC transporter superfamily An updated overview, relevance in cancer multidrug resistance and perspectives with personalized medicine. Mol. Biol. Rep. 2021, 48, 1883-1901. [CrossRef] [PubMed]

33. Mitchell-White, J.I.; Stockner, T.; Holliday, N.; Briddon, S.J.; Kerr, I.D. Analysis of Sequence Divergence in Mammalian ABCGs Predicts a Structural Network of Residues That Underlies Functional Divergence. Int. J. Mol. Sci. 2021, 22, 3012. [CrossRef] [PubMed]

34. Theile, D.; Wizgall, P. Acquired ABC-transporter overexpression in cancer cells: Transcriptional induction or Darwinian selection? Naunyn Schmiedebergs Arch. Pharmacol. 2021, 394, 1621-1632. [CrossRef]

35. Gao, L.; Morine, Y.; Yamada, S.; Saito, Y.; Ikemoto, T.; Tokuda, K.; Takasu, C.; Miyazaki, K.; Shimada, M. Nrf2 signaling promotes cancer stemness, migration, and expression of ABC transporter genes in sorafenib-resistant hepatocellular carcinoma cells. PLoS ONE 2021, 16, e0256755. [CrossRef] [PubMed]

36. Zhang, J.; Zhang, X.; Li, J.; Song, Z. Systematic analysis of the ABC transporter family in hepatocellular carcinoma reveals the importance of ABCB6 in regulating ferroptosis. Life Sci. 2020, 257, 118131. [CrossRef]

37. Salaroglio, I.C.; Panada, E.; Moiso, E.; Buondonno, I.; Provero, P.; Rubinstein, M.; Kopecka, J.; Riganti, C. PERK induces resistance to cell death elicited by endoplasmic reticulum stress and chemotherapy. Mol. Cancer 2017, 16, 91. [CrossRef]

38. Leung, H.W.; Lau, E.Y.T.; Leung, C.O.N.; Lei, M.M.L.; Mok, E.H.K.; Ma, V.W.S.; Cho, W.C.S.; Ng, I.O.L.; Yun, J.P.; Cai, S.H.; et al NRF2/SHH signaling cascade promotes tumor-initiating cell lineage and drug resistance in hepatocellular carcinoma. Cancer Lett. 2020, 476, 48-56. [CrossRef]

39. Singh, A.; Wu, H.; Zhang, P.; Happel, C.; Ma, J.; Biswal, S. Expression of ABCG2 (BCRP) is regulated by Nrf2 in cancer cells that confers side population and chemoresistance phenotype. Mol. Cancer Ther. 2010, 9, 2365-2376. [CrossRef]

40. Raghunath, A.; Sundarraj, K.; Arfuso, F.; Sethi, G.; Perumal, E. Dysregulation of Nrf2 in Hepatocellular Carcinoma: Role in Cancer Progression and Chemoresistance. Cancers 2018, 10, 481. [CrossRef]

41. Cullinan, S.B.; Zhang, D.; Hannink, M.; Arvisais, E.; Kaufman, R.J.; Diehl, J.A. Nrf2 is a direct PERK substrate and effector of PERK-dependent cell survival. Mol. Cell Biol. 2003, 23, 7198-7209. [CrossRef]

42. Lin, J.C.; Yang, P.M.; Liu, T.P. PERK/ATF4-Dependent ZFAS1 Upregulation Is Associated with Sorafenib Resistance in Hepatocellular Carcinoma Cells. Int. J. Mol. Sci. 2021, 22, 5848. [CrossRef] [PubMed]

43. Rojas-Rivera, D.; Delvaeye, T.; Roelandt, R.; Nerinckx, W.; Augustyns, K.; Vandenabeele, P.; Bertrand, M.J.M. When PERK inhibitors turn out to be new potent RIPK1 inhibitors: Critical issues on the specificity and use of GSK2606414 and GSK2656157. Cell Death Differ. 2017, 24, 1100-1110. [CrossRef] [PubMed]

44. Gao, Q.; Li, X.X.; Xu, Y.M.; Zhang, J.Z.; Rong, S.D.; Qin, Y.Q.; Fang, J. IRE1alpha-targeting downregulates ABC transporters and overcomes drug resistance of colon cancer cells. Cancer Lett. 2020, 476, 67-74. [CrossRef] [PubMed]

45. Avril, T.; Chevet, E. IRE1-mediated miRNA maturation in macrophage phosphoinositide signaling. EMBO Rep. 2020, 21, e51929. [CrossRef] [PubMed]

46. Zhang, K.; Liu, H.; Song, Z.; Jiang, Y.; Kim, H.; Samavati, L.; Nguyen, H.M.; Yang, Z.Q. The UPR Transducer IRE1 Promotes Breast Cancer Malignancy by Degrading Tumor Suppressor microRNAs. iScience 2020, 23, 101503. [CrossRef]

47. Heindryckx, F.; Binet, F.; Ponticos, M.; Rombouts, K.; Lau, J.; Kreuger, J.; Gerwins, P. Endoplasmic reticulum stress enhances fibrosis through IRE1alpha-mediated degradation of miR-150 and XBP-1 splicing. EMBO Mol. Med. 2016, 8, 729-744. [CrossRef]

48. Kim, T.; Croce, C.M. MicroRNA and ER stress in cancer. Semin. Cancer Biol. 2021, 75, 3-14. [CrossRef]

49. Shi, L.; Wu, L.; Chen, Z.; Yang, J.; Chen, X.; Yu, F.; Zheng, F.; Lin, X. MiR-141 Activates Nrf2-Dependent Antioxidant Pathway via Down-Regulating the Expression of Keap1 Conferring the Resistance of Hepatocellular Carcinoma Cells to 5-Fluorouracil. Cell Physiol. Biochem. 2015, 35, 2333-2348. [CrossRef]

50. Kishikawa, T.; Otsuka, M.; Tan, P.S.; Ohno, M.; Sun, X.; Yoshikawa, T.; Shibata, C.; Takata, A.; Kojima, K.; Takehana, K.; et al. Decreased miR122 in hepatocellular carcinoma leads to chemoresistance with increased arginine. Oncotarget 2015, 6, 8339-8352. [CrossRef]

51. Gao, R.; Kalathur, R.K.R.; Coto-Llerena, M.; Ercan, C.; Buechel, D.; Shuang, S.; Piscuoglio, S.; Dill, M.T.; Camargo, F.D.; Christofori, G.; et al. YAP/TAZ and ATF4 drive resistance to Sorafenib in hepatocellular carcinoma by preventing ferroptosis. EMBO Mol. Med. 2021, 13, e14351. [CrossRef]

52. Baglini, E.; Salerno, S.; Barresi, E.; Robello, M.; Da Settimo, F.; Taliani, S.; Marini, A.M. Multiple Topoisomerase I (TopoI), Topoisomerase II (TopoII) and Tyrosyl-DNA Phosphodiesterase (TDP) inhibitors in the development of anticancer drugs. Eur. J. Pharm. Sci. 2021, 156, 105594. [CrossRef] [PubMed]

53. Hughes, C.S.; Shen, J.W.; Subjeck, J.R. Resistance to etoposide induced by three glucose-regulated stresses in Chinese hamster ovary cells. Cancer Res. 1989, 49, 4452-4454. [PubMed] 
54. Gray, M.D.; Mann, M.; Nitiss, J.L.; Hendershot, L.M. Activation of the unfolded protein response is necessary and sufficient for reducing topoisomerase IIalpha protein levels and decreasing sensitivity to topoisomerase-targeted drugs. Mol. Pharmacol. 2005, 68, 1699-1707. [CrossRef] [PubMed]

55. Dufey, E.; Bravo-San Pedro, J.M.; Eggers, C.; Gonzalez-Quiroz, M.; Urra, H.; Sagredo, A.I.; Sepulveda, D.; Pihan, P.; CarrerasSureda, A.; Hazari, Y.; et al. Genotoxic stress triggers the activation of IRE1alpha-dependent RNA decay to modulate the DNA damage response. Nat. Commun. 2020, 11, 2401. [CrossRef] [PubMed]

56. Mann, M.J.; Pereira, E.R.; Liao, N.; Hendershot, L.M. UPR-induced resistance to etoposide is downstream of PERK and independent of changes in topoisomerase IIalpha levels. PLoS ONE 2012, 7, e47931. [CrossRef] [PubMed]

57. Fu, X.T.; Song, K.; Zhou, J.; Shi, Y.H.; Liu, W.R.; Tian, M.X.; Jin, L.; Shi, G.M.; Gao, Q.; Ding, Z.B.; et al. Autophagy activation contributes to glutathione transferase Mu 1-mediated chemoresistance in hepatocellular carcinoma. Oncol. Lett. 2018, 16, 346-352. [CrossRef] [PubMed]

58. Chun, Y.; Kim, J. Autophagy: An Essential Degradation Program for Cellular Homeostasis and Life. Cells 2018, 7, 278. [CrossRef]

59. Robin, S.K.D.; Ansari, M.; Uppugunduri, C.R.S. Spectrophotometric Screening for Potential Inhibitors of Cytosolic Glutathione S-Transferases. J. Vis. Exp. 2020, 164, e61347. [CrossRef]

60. Shi, Y.H.; Ding, Z.B.; Zhou, J.; Hui, B.; Shi, G.M.; Ke, A.W.; Wang, X.Y.; Dai, Z.; Peng, Y.F.; Gu, C.Y.; et al. Targeting autophagy enhances sorafenib lethality for hepatocellular carcinoma via ER stress-related apoptosis. Autophagy 2011, 7, 1159-1172. [CrossRef]

61. Zhang, J.; Ye, Z.W.; Chen, W.; Culpepper, J.; Jiang, H.; Ball, L.E.; Mehrotra, S.; Blumental-Perry, A.; Tew, K.D.; Townsend, D.M. Altered redox regulation and S-glutathionylation of BiP contribute to bortezomib resistance in multiple myeloma. Free Radic. Biol. Med. 2020, 160, 755-767. [CrossRef]

62. Dubbelboer, I.R.; Pavlovic, N.; Heindryckx, F.; Sjogren, E.; Lennernas, H. Liver Cancer Cell Lines Treated with Doxorubicin under Normoxia and Hypoxia: Cell Viability and Oncologic Protein Profile. Cancers 2019, 11, 1024. [CrossRef] [PubMed]

63. Oshi, M.; Kim, T.H.; Tokumaru, Y.; Yan, L.; Matsuyama, R.; Endo, I.; Cherkassky, L.; Takabe, K. Enhanced DNA Repair Pathway is Associated with Cell Proliferation and Worse Survival in Hepatocellular Carcinoma (HCC). Cancers 2021, 13, 323. [CrossRef] [PubMed]

64. Pavan, I.C.B.; Peres de Oliveira, A.; Dias, P.R.F.; Basei, F.L.; Issayama, L.K.; Ferezin, C.C.; Silva, F.R.; Rodrigues de Oliveira, A.L.; Alves Dos Reis Moura, L.; Martins, M.B.; et al. On Broken Ne(c)ks and Broken DNA: The Role of Human NEKs in the DNA Damage Response. Cells 2021, 10, 507. [CrossRef] [PubMed]

65. Sakthivel, K.M.; Hariharan, S. Regulatory players of DNA damage repair mechanisms: Role in Cancer Chemoresistance. Biomed. Pharmacother. 2017, 93, 1238-1245. [CrossRef]

66. Yuan, H.; Lu, Y.; Chan, Y.-T.; Zhang, C.; Wang, N.; Feng, Y. The Role of Protein SUMOylation in Human Hepatocellular Carcinoma: A Potential Target of New Drug Discovery and Development. Cancers 2021, 13, 5700. [CrossRef]

67. Zhang, S.; Fu, Y.; Wang, D.; Wang, J. Icotinib enhances lung cancer cell radiosensitivity in vitro and in vivo by inhibiting MAPK/ERK and AKT activation. Clin. Exp. Pharmacol. Physiol. 2018, 45, 969-977. [CrossRef]

68. Che, J.; Lu, Y.W.; Sun, K.K.; Feng, C.; Dong, A.J.; Jiao, Y. Overexpression of TOB1 confers radioprotection to bronchial epithelial cells through the MAPK/ERK pathway. Oncol. Rep. 2013, 30, 637-642. [CrossRef]

69. Marza, E.; Taouji, S.; Barroso, K.; Raymond, A.A.; Guignard, L.; Bonneu, M.; Pallares-Lupon, N.; Dupuy, J.W.; Fernandez-Zapico, M.E.; Rosenbaum, J.; et al. Genome-wide screen identifies a novel p97/CDC-48-dependent pathway regulating ER-stress-induced gene transcription. EMBO Rep. 2015, 16, 332-340. [CrossRef]

70. Pantazi, V.; Berzsenyi, I.; Borsos, B.N.; Pankotai, T. Visualizing and Quantifying Endonuclease-Based Site-Specific DNA Damage. J. Vis. Exp. 2021, 174, e62175. [CrossRef]

71. Williams, A.B.; Schumacher, B. p53 in the DNA-Damage-Repair Process. Cold Spring Harb. Perspect. Med. 2016, 6, a026070. [CrossRef]

72. Kroemer, G.; Bravo-San Pedro, J.M.; Galluzzi, L. Novel function of cytoplasmic p53 at the interface between mitochondria and the endoplasmic reticulum. Cell Death Dis. 2015, 6, e1698. [CrossRef] [PubMed]

73. Lin, W.C.; Chuang, Y.C.; Chang, Y.S.; Lai, M.D.; Teng, Y.N.; Su, I.J.; Wang, C.C.; Lee, K.H.; Hung, J.H. Endoplasmic reticulum stress stimulates p53 expression through NF-kappaB activation. PLoS ONE 2012, 7, e39120.

74. Pluquet, O.; Qu, L.K.; Baltzis, D.; Koromilas, A.E. Endoplasmic reticulum stress accelerates p53 degradation by the cooperative actions of Hdm2 and glycogen synthase kinase 3beta. Mol. Cell Biol. 2005, 25, 9392-9405. [CrossRef] [PubMed]

75. Qu, L.; Huang, S.; Baltzis, D.; Rivas-Estilla, A.M.; Pluquet, O.; Hatzoglou, M.; Koumenis, C.; Taya, Y.; Yoshimura, A.; Koromilas, A.E. Endoplasmic reticulum stress induces p53 cytoplasmic localization and prevents p53-dependent apoptosis by a pathway involving glycogen synthase kinase-3beta. Genes Dev. 2004, 18, 261-277. [CrossRef] [PubMed]

76. Fu, Y.; Li, J.; Lee, A.S. GRP78/BiP inhibits endoplasmic reticulum BIK and protects human breast cancer cells against estrogen starvation-induced apoptosis. Cancer Res. 2007, 67, 3734-3740. [CrossRef] [PubMed]

77. Zhang, F.; Hamanaka, R.B.; Bobrovnikova-Marjon, E.; Gordan, J.D.; Dai, M.S.; Lu, H.; Simon, M.C.; Diehl, J.A. Ribosomal stress couples the unfolded protein response to p53-dependent cell cycle arrest. J. Biol. Chem. 2006, 281, 30036-30045. [CrossRef]

78. Mihailidou, C.; Papazian, I.; Papavassiliou, A.G.; Kiaris, H. CHOP-dependent regulation of p21/waf1 during ER stress. Cell Physiol. Biochem. 2010, 25, 761-766. [CrossRef] 
79. Inoue, Y.; Kawachi, S.; Ohkubo, T.; Nagasaka, M.; Ito, S.; Fukuura, K.; Itoh, Y.; Ohoka, N.; Morishita, D.; Hayashi, H. The CDK inhibitor p21 is a novel target gene of ATF4 and contributes to cell survival under ER stress. FEBS Lett. 2017, 591, 3682-3691. [CrossRef]

80. O'Callaghan, P.; Zarb, Y.; Noborn, F.; Kreuger, J. Modeling the structural implications of an alternatively spliced Exoc312, a paralog of the tunneling nanotube-forming M-Sec. PLoS ONE 2018, 13, e0201557. [CrossRef]

81. Fusee, L.T.S.; Marin, M.; Fahraeus, R.; Lopez, I. Alternative Mechanisms of p53 Action During the Unfolded Protein Response. Cancers 2020, 12, 401. [CrossRef]

82. Darling, N.J.; Cook, S.J. The role of MAPK signalling pathways in the response to endoplasmic reticulum stress. Biochim. Biophys. Acta 2014, 1843, 2150-2163. [CrossRef] [PubMed]

83. Shi, Z.; Yu, X.; Yuan, M.; Lv, W.; Feng, T.; Bai, R.; Zhong, H. Activation of the PERK-ATF4 pathway promotes chemo-resistance in colon cancer cells. Sci. Rep. 2019, 9, 3210. [CrossRef] [PubMed]

84. Kim, M.J.; Yun, G.J.; Kim, S.E. Metabolic Regulation of Ferroptosis in Cancer. Biology 2021, 10, 83. [CrossRef] [PubMed]

85. Stieger, B.; Steiger, J.; Locher, K.P. Membrane lipids and transporter function. Biochim. Biophys. Acta Mol. Basis Dis. 2021, 1867, 166079. [CrossRef] [PubMed]

86. Zhou, T.; Lv, X.; Guo, X.; Ruan, B.; Liu, D.; Ding, R.; Gao, Y.; Ding, J.; Dou, K.; Chen, Y. RACK1 modulates apoptosis induced by sorafenib in HCC cells by interfering with the IRE1/XBP1 axis. Oncol. Rep. 2015, 33, 3006-3014. [CrossRef]

87. Orru, C.; Giordano, S.; Columbano, A. Nrf2 in Neoplastic and Non-Neoplastic Liver Diseases. Cancers 2020, 12, 2932. [CrossRef]

88. Zhou, S.; Ye, W.; Zhang, Y.; Yu, D.; Shao, Q.; Liang, J.; Zhang, M. miR-144 reverses chemoresistance of hepatocellular carcinoma cell lines by targeting Nrf2-dependent antioxidant pathway. Am. J. Transl. Res. 2016, 8, 2992-3002.

89. Gonzalez-Sanchez, E.; Marin, J.J.; Perez, M.J. The expression of genes involved in hepatocellular carcinoma chemoresistance is affected by mitochondrial genome depletion. Mol. Pharm. 2014, 11, 1856-1868. [CrossRef]

90. Bronner, D.N.; O’Riordan, M.X. Measurement of Mitochondrial DNA Release in Response to ER Stress. Bio-Protocol 2016, 6, e1839. [CrossRef]

91. Souza-Neto, F.V.; Jimenez-Gonzalez, S.; Delgado-Valero, B.; Jurado-Lopez, R.; Genty, M.; Romero-Miranda, A.; Rodriguez, C.; Nieto, M.L.; Martinez-Martinez, E.; Cachofeiro, V. The Interplay of Mitochondrial Oxidative Stress and Endoplasmic Reticulum Stress in Cardiovascular Fibrosis in Obese Rats. Antioxidants 2021, 10, 1274. [CrossRef] [PubMed]

92. Kumar, V.; Maity, S. ER Stress-Sensor Proteins and ER-Mitochondrial Crosstalk-Signaling Beyond (ER) Stress Response. Biomolecules 2021, 11, 173. [CrossRef] [PubMed]

93. Fan, P.; Tyagi, A.K.; Agboke, F.A.; Mathur, R.; Pokharel, N.; Jordan, V.C. Modulation of nuclear factor-kappa B activation by the endoplasmic reticulum stress sensor PERK to mediate estrogen-induced apoptosis in breast cancer cells. Cell Death Discov. 2018, 4 15. [CrossRef] [PubMed]

94. Makhov, P.; Naito, S.; Haifler, M.; Kutikov, A.; Boumber, Y.; Uzzo, R.G.; Kolenko, V.M. The convergent roles of NF-kappaB and ER stress in sunitinib-mediated expression of pro-tumorigenic cytokines and refractory phenotype in renal cell carcinoma. Cell Death Dis. 2018, 9, 374. [CrossRef]

95. Schmitz, M.L.; Shaban, M.S.; Albert, B.V.; Gokcen, A.; Kracht, M. The Crosstalk of Endoplasmic Reticulum (ER) Stress Pathways with NF-kappaB: Complex Mechanisms Relevant for Cancer, Inflammation and Infection. Biomedicines 2018, 6, 58. [CrossRef] [PubMed]

96. Liu, F.T.; Jia, L.; Wang, P.; Wang, H.; Farren, T.W.; Agrawal, S.G. STAT3 and NF-kappaB cooperatively control in vitro spontaneous apoptosis and poor chemo-responsiveness in patients with chronic lymphocytic leukemia. Oncotarget 2016, 7, 32031-32045. [CrossRef]

97. Grivennikov, S.I.; Karin, M. Dangerous liaisons: STAT3 and NF-kappaB collaboration and crosstalk in cancer. Cytokine Growth Factor Rev. 2010, 21, 11-19. [CrossRef]

98. Cho, J.; Min, H.Y.; Pei, H.; Wei, X.; Sim, J.Y.; Park, S.H.; Hwang, S.J.; Lee, H.J.; Hong, S.; Shin, Y.K.; et al. The ATF6-EGF Pathway Mediates the Awakening of Slow-Cycling Chemoresistant Cells and Tumor Recurrence by Stimulating Tumor Angiogenesis. Cancers 2020, 12, 1772. [CrossRef]

99. Van Huizen, R.; Martindale, J.L.; Gorospe, M.; Holbrook, N.J. P58IPK, a novel endoplasmic reticulum stress-inducible protein and potential negative regulator of eIF2alpha signaling. J. Biol. Chem. 2003, 278, 15558-15564. [CrossRef]

100. DeZwaan-McCabe, D.; Riordan, J.D.; Arensdorf, A.M.; Icardi, M.S.; Dupuy, A.J.; Rutkowski, D.T. The stress-regulated transcription factor CHOP promotes hepatic inflammatory gene expression, fibrosis, and oncogenesis. PLoS Genet. 2013, 9, e1003937. [CrossRef]

101. Scaiewicz, V.; Nahmias, A.; Chung, R.T.; Mueller, T.; Tirosh, B.; Shibolet, O. CCAAT/enhancer-binding protein homologous (CHOP) protein promotes carcinogenesis in the DEN-induced hepatocellular carcinoma model. PLoS ONE 2013, 8, e81065. [CrossRef]

102. Hu, H.; Tian, M.; Ding, C.; Yu, S. The C/EBP Homologous Protein (CHOP) Transcription Factor Functions in Endoplasmic Reticulum Stress-Induced Apoptosis and Microbial Infection. Front. Immunol. 2018, 9, 3083. [CrossRef] [PubMed]

103. Bogaerts, E.; Heindryckx, F.; Devisscher, L.; Paridaens, A.; Vandewynckel, Y.P.; Van den Bussche, A.; Verhelst, X.; Libbrecht, L.; van Grunsven, L.A.; Geerts, A.; et al. Time-dependent effect of hypoxia on tumor progression and liver progenitor cell markers in primary liver tumors. PLoS ONE 2015, 10, e0119555. [CrossRef] [PubMed] 
104. Heindryckx, F.; Coulon, S.; Terrie, E.; Casteleyn, C.; Stassen, J.M.; Geerts, A.; Libbrecht, L.; Allemeersch, J.; Carmeliet, P.; Colle, I.; et al. The placental growth factor as a target against hepatocellular carcinoma in a diethylnitrosamine-induced mouse model. $J$. Hepatol. 2013, 58, 319-328. [CrossRef] [PubMed]

105. Heindryckx, F.; Kuchnio, A.; Casteleyn, C.; Coulon, S.; Olievier, K.; Colle, I.; Geerts, A.; Libbrecht, L.; Carmeliet, P.; Van Vlierberghe, H. Effect of prolyl hydroxylase domain-2 haplodeficiency on the hepatocarcinogenesis in mice. J. Hepatol. 2012, 57, 61-68. [CrossRef]

106. Vu, N.B.; Nguyen, T.T.; Tran, L.C.; Do, C.D.; Nguyen, B.H.; Phan, N.K.; Pham, P.V. Doxorubicin and 5-fluorouracil resistant hepatic cancer cells demonstrate stem-like properties. Cytotechnology 2013, 65, 491-503. [CrossRef]

107. Pi, L.; Li, X.; Song, Q.; Shen, Y.; Lu, X.; Di, B. Knockdown of glucose-regulated protein 78 abrogates chemoresistance of hypopharyngeal carcinoma cells to cisplatin induced by unfolded protein in response to severe hypoxia. Oncol. Lett. 2014, 7 , 685-692. [CrossRef]

108. You, Y.; Zheng, Q.; Dong, Y.; Xie, X.; Wang, Y.; Wu, S.; Zhang, L.; Wang, Y.; Xue, T.; Wang, Z.; et al. Matrix stiffness-mediated effects on stemness characteristics occurring in HCC cells. Oncotarget 2016, 7, 32221-32231. [CrossRef]

109. Tameire, F.; Verginadis, I.I.; Koumenis, C. Cell intrinsic and extrinsic activators of the unfolded protein response in cancer: Mechanisms and targets for therapy. Semin. Cancer Biol. 2015, 33, 3-15. [CrossRef]

110. Ozkan, A.; Stolley, D.L.; Cressman, E.N.K.; McMillin, M.; DeMorrow, S.; Yankeelov, T.E.; Rylander, M.N. Tumor Microenvironment Alters Chemoresistance of Hepatocellular Carcinoma Through CYP3A4 Metabolic Activity. Front. Oncol. 2021, 11, 662135. [CrossRef]

111. Calitz, C.; Pavlovic, N.; Rosenquist, J.; Zagami, C.; Samanta, A.; Heindryckx, F. A Biomimetic Model for Liver Cancer to Study Tumor-Stroma Interactions in a 3D Environment with Tunable Bio-Physical Properties. J. Vis. Exp. 2020, 162, e61606. [CrossRef]

112. Samarelli, A.V.; Masciale, V.; Aramini, B.; Coló, G.P.; Tonelli, R.; Marchioni, A.; Bruzzi, G.; Gozzi, F.; Andrisani, D.; Castaniere, I.; et al. Molecular Mechanisms and Cellular Contribution from Lung Fibrosis to Lung Cancer Development. Int. J. Mol. Sci. 2021, 22, 12179. [CrossRef] [PubMed]

113. Kaps, L.; Schuppan, D. Targeting Cancer Associated Fibroblasts in Liver Fibrosis and Liver Cancer Using Nanocarriers. Cells 2020, 9, 2027. [CrossRef]

114. Maiers, J.L.; Kostallari, E.; Mushref, M.; de Assuncao, T.M.; Li, H.; Jalan-Sakrikar, N.; Huebert, R.C.; Cao, S.; Malhi, H.; Shah, V.H. The unfolded protein response mediates fibrogenesis and collagen I secretion through regulating TANGO1 in mice. Hepatology 2017, 65, 983-998. [CrossRef]

115. Liu, Z.; Li, C.; Kang, N.; Malhi, H.; Shah, V.H.; Maiers, J.L. Transforming growth factor beta (TGFbeta) cross-talk with the unfolded protein response is critical for hepatic stellate cell activation. J. Biol. Chem. 2019, 294, 3137-3151. [CrossRef]

116. Jia, C.; Wang, G.; Wang, T.; Fu, B.; Zhang, Y.; Huang, L.; Deng, Y.; Chen, G.; Wu, X.; Chen, J.; et al. Cancer-associated Fibroblasts induce epithelial-mesenchymal transition via the Transglutaminase 2-dependent IL-6/IL6R/STAT3 axis in Hepatocellular Carcinoma. Int. J. Biol. Sci. 2020, 16, 2542-2558. [CrossRef] [PubMed]

117. Palamaris, K.; Felekouras, E.; Sakellariou, S. Epithelial to Mesenchymal Transition: Key Regulator of Pancreatic Ductal Adenocarcinoma Progression and Chemoresistance. Cancers 2021, 13, 5532. [CrossRef]

118. Hirao, A.; Sato, Y.; Tanaka, H.; Nishida, K.; Tomonari, T.; Hirata, M.; Bando, M.; Kida, Y.; Tanaka, T.; Kawaguchi, T.; et al. MiR125b-5p Is Involved in Sorafenib Resistance through Ataxin-1-Mediated Epithelial-Mesenchymal Transition in Hepatocellular Carcinoma. Cancers 2021, 13, 4917. [CrossRef] [PubMed]

119. Gibert-Ramos, A.; Sanfeliu-Redondo, D.; Aristu-Zabalza, P.; Martínez-Alcocer, A.; Gracia-Sancho, J.; Guixé-Muntet, S.; FernándezIglesias, A. The Hepatic Sinusoid in Chronic Liver Disease: The Optimal Milieu for Cancer. Cancers 2021, 13, 5719. [CrossRef]

120. Arvanitakis, K.; Koletsa, T.; Mitroulis, I.; Germanidis, G. Tumor-Associated Macrophages in Hepatocellular Carcinoma Pathogenesis, Prognosis and Therapy. Cancers 2022, 14, 226. [CrossRef]

121. Fu, X.T.; Song, K.; Zhou, J.; Shi, Y.H.; Liu, W.R.; Shi, G.M.; Gao, Q.; Wang, X.Y.; Ding, Z.B.; Fan, J. Tumor-associated macrophages modulate resistance to oxaliplatin via inducing autophagy in hepatocellular carcinoma. Cancer Cell Int. 2019, 19, 71. [CrossRef]

122. Pavlovic, N.; Kopsida, M.; Gerwins, P.; Heindryckx, F. Inhibiting P2Y12 in Macrophages Induces Endoplasmic Reticulum Stress and Promotes an Anti-Tumoral Phenotype. Int. J. Mol. Sci. 2020, 21, 8177. [CrossRef]

123. Yang, F.; Liu, Y.; Ren, H.; Zhou, G.; Yuan, X.; Shi, X. ER-stress regulates macrophage polarization through pancreatic EIF-2alpha kinase. Cell Immunol. 2019, 336, 40-47. [CrossRef]

124. Suzuki, T.; Gao, J.; Ishigaki, Y.; Kondo, K.; Sawada, S.; Izumi, T.; Uno, K.; Kaneko, K.; Tsukita, S.; Takahashi, K.; et al. ER Stress Protein CHOP Mediates Insulin Resistance by Modulating Adipose Tissue Macrophage Polarity. Cell Rep. 2017, 18, $2045-2057$. [CrossRef] [PubMed]

125. Dasgupta, D.; Nakao, Y.; Mauer, A.S.; Thompson, J.M.; Sehrawat, T.S.; Liao, C.Y.; Krishnan, A.; Lucien, F.; Guo, Q.; Liu, M.; et al. IRE1A Stimulates Hepatocyte-Derived Extracellular Vesicles That Promote Inflammation in Mice With Steatohepatitis. Gastroenterology 2020, 159, 1487-1503.e17. [CrossRef] [PubMed]

126. Hasnain, S.Z.; Lourie, R.; Das, I.; Chen, A.C.; McGuckin, M.A. The interplay between endoplasmic reticulum stress and inflammation. Immunol. Cell Biol. 2012, 90, 260-270. [CrossRef]

127. Arvanitakis, K.; Mitroulis, I.; Germanidis, G. Tumor-Associated Neutrophils in Hepatocellular Carcinoma Pathogenesis, Prognosis, and Therapy. Cancers 2021, 13, 2899. [CrossRef] [PubMed] 
128. Garcia-Navas, R.; Gajate, C.; Mollinedo, F. Neutrophils drive endoplasmic reticulum stress-mediated apoptosis in cancer cells through arginase-1 release. Sci. Rep. 2021, 11, 12574. [CrossRef] [PubMed]

129. Setrerrahmane, S.; Xu, H. Tumor-related interleukins: Old validated targets for new anti-cancer drug development. Mol. Cancer 2017, 16, 153. [CrossRef] [PubMed]

130. Dai, Z.; Wang, X.; Peng, R.; Zhang, B.; Han, Q.; Lin, J.; Wang, J.; Lin, J.; Jiang, M.; Liu, H.; et al. Induction of IL-6Ralpha by ATF3 enhances IL-6 mediated sorafenib and regorafenib resistance in hepatocellular carcinoma. Cancer Lett. 2022, 524, 161-171. [CrossRef]

131. Fang, P.; Xiang, L.; Huang, S.; Jin, L.; Zhou, G.; Zhuge, L.; Li, J.; Fan, H.; Zhou, L.; Pan, C.; et al. IRE1alpha-XBP1 signaling pathway regulates IL-6 expression and promotes progression of hepatocellular carcinoma. Oncol. Lett. 2018, 16, 4729-4736.

132. Lohitesh, K.; Chowdhury, R.; Mukherjee, S. Resistance a major hindrance to chemotherapy in hepatocellular carcinoma: An insight. Cancer Cell Int. 2018, 18, 44. [CrossRef] [PubMed]

133. Chen, X.; Cubillos-Ruiz, J.R. Endoplasmic reticulum stress signals in the tumour and its microenvironment. Nat. Rev. Cancer 2021, 21, 71-88. [CrossRef] [PubMed] 